\title{
Introduction to the Advances in Design Research for Information Systems Minitrack
}

\author{
Richard Baskerville \\ Georgia State University \\ Curtin University \\ baskerville@gsu.edu
}

\author{
Roman Beck \\ IT University of Copenhagen \\ romb@itu.dk
}

\author{
Tuure Tuunanen \\ University of Jyväskylä \\ Faculty of IT \\ tuure@tuunanen.fi
}

This minitrack provides a venue for information systems (IS) design researchers to share their work and interact with likeminded scholars. Design research is a prominent form of engaged scholarship, which combines inquiry with a potential for action and intervention. Design research can encompass at least three major subfields.

The history of the minitrack originates as design theory research, anchored to the seminal work by founding chairs Joe Walls, George Widmeyer and Omar El Sawy [1]. This origin focused on the development of theories about creating new or improved information systems based on kernel or grand theories. The IS design theory concept has continued development for two decades since [2-4].

Today, the minitrack also attracts design science research, which focuses on creating 'new-to-theworld' IS artifacts [5-7]. We not only offer an outlet for researchers doing artifact driven research in information systems, but also in other fields such as industrial engineering or service design. Furthermore, design research is welcome that focuses on the study of how designers actually conduct design activities, e.g., science of design research. Papers in this subfield could potentially come not only from IS, but also from architecture and design. All three subfields are often (but not always) tightly engaged with design practice and frequently embody participative forms of research that rest on the advice and perspectives of multiple stakeholders in understanding a complex social problem.

The papers included in this year's minitrack cover the topics of philosophy of research and more specifically looking at IT artifact and code refactoring and IT artifacts and critical realism. Interestingly, we have also started to see how design science research has begun to have impact on service research. One of the papers included this year looks at how to support client profiling in financial service encounters and how develop a software application to support this process. It is interesting to see similar applications design science research are being also published in service research journals, such the premier research outlet in the field: J. of Service Research. We encourage other researchers to join this effort and submit similar manuscripts to us in future years. It would be also highly interesting how design science research could be applied other fields of research, such as industrial engineering or operations management and/or research. Finally, our fourth paper this year looks at how to chart the design science research discourse and specifically the incongruence between the methodological guidelines informing the design and how the design is carried out in practice in years 2004-2013.

\section{References}

[1] J. G. Walls, G. R. Widmeyer, and O. A. El Sawy, "Building an information system design theory for vigilant EIS," Information Systems Research, vol. 3, pp. 36-59, 1992.

[2] S. Gregor and A. R. Hevner, "Positioning and presenting design science reseach for maximum impact," MIS Quarterly, vol. 37, 2013.

[3] S. T. March and G. F. Smith, "Design and natural science research on information technology," Decision Support Systems, vol. 15, pp. 251-266, 1995.

[4] S. Gregor and D. Jones, "The anatomy of a design theory," Journal of the Association of Information Systems, vol. 8, pp. 312-335, May 20072007.

[5] A. R. Hevner, S. T. March, and J. Park, "Design Research in Information Systems Research," MIS Quarterly, vol. 28, pp. 75105, 2004.

[6] K. Peffers, T. Tuunanen, M. Rothenberger, and S. Chatterjee, "A Design Science Research Methodology for Information Systems Research," Journal of Management Information Systems, vol. 24, pp. 45-78, Winter 2007-8 2008.

[7] M. K. Sein, O. Henfridsson, S. Purao, M. Rossi, and R. Lindgren, "Action Design Research," MIS Quarterly, vol. 35, 2011. 